\title{
Maize (Zea mays L.) Growth and Grain Yield under Conventional and Site-Specific Nitrogen Management in a Dryland Farming System
}

\author{
Suzan Mashego ${ }^{1,2}$, Brilliant Mareme Petja ${ }^{1,2}$, Matshwene Edwin Moshia ${ }^{3}$ and Shadrack Batsile Dikgwatlhe ${ }^{1,4}$ \\ 1. Limpopo Department of Agriculture, Directorate of Research Services, Polokwane 0700, South Africa \\ 2. Department of Plant Production, Soil Science and Agricultural Engineering, University of Limpopo, Sovenga 0727, South Africa \\ 3. Department of Crop Science, Tshwane University of Technology, Pretoria 0001, South Africa \\ 4. College of Agronomy and Biotechnology, China Agricultural University, Beijing 100094, China
}

Received: May 31, 2014 / Published: August 20, 2014.

\begin{abstract}
Large amount of pre-plant nitrogen $(\mathrm{N})$ fertilizer results in low $\mathrm{N}$ use efficiency due to poor synchrony between soil $\mathrm{N}$ supply and maize $\mathrm{N}$ demand, especially during $\mathrm{N}$ sensitive growth stages. The objectives of the study were to compare growth and yield of maize (Zea mays L.) under conventional and site-specific $\mathrm{N}$ management in a dryland farming system. The study, which was designed as randomized complete block design was conducted over three site-years under continuous maize cropping system in the semi-arid regions of the Limpopo Province in South Africa. Treatments of the study consisted of three N management strategies on a maize field planted to drought resistant SNK 2147 hybrid maize cultivar. Treatments were: (i) no N application (N0), (ii) site-specific $\mathrm{N}$ at variable rates ranging between $18 \mathrm{~kg} \mathrm{~N} / \mathrm{ha}$ and $33 \mathrm{~kg} \mathrm{~N} / \mathrm{ha}$ based on soil analysis results (N1) and (iii) conventional and uniform $\mathrm{N}$ application broadcasted during planting at $58 \mathrm{~kg} \mathrm{~N} / \mathrm{ha}$ (N2). Sufficiency index as indication of N deficiency was determined using CCM-200 on maize leaves based on leaf numbers during maize vegetative growth stages V6, V10 and V14, and thereafter N was applied only when needed. The highest maize grain yield of $5.2 \mathrm{Mg} / \mathrm{ha}$ for $\mathrm{N} 1$ was significantly higher $(P \leq 0.05)$ than $3.2 \mathrm{Mg} / \mathrm{ha}$ and $4.0 \mathrm{Mg} /$ ha of N0 and N2 in site-year I, respectively. Maize grain yield of $2.2 \mathrm{Mg} / \mathrm{ha}(\mathrm{N} 1)$ at site-year II was significantly higher $(P \leq$ 0.05 ) than $1.7 \mathrm{Mg} / \mathrm{ha}$ of the N0. The maize growth and yield under N2 and N1 was compared, N1 required between $43 \%$ and $69 \%$ lesser $\mathrm{N}$ fertilizer as compared to N2 over site-years, and resulted in higher maize height, number of leaves per plant, leaf length, and leaf area than that of conventional $\mathrm{N}$ management strategy. Therefore, site-specific $\mathrm{N}$ management strategy sustains and improves growth and yield of maize using minimal $\mathrm{N}$ fertilizer as compared to conventional approach in low fertility soils of semi-arid regions in dryland farming systems. In examining the results of this study, there was a consistent benefit of site-specific $\mathrm{N}$ management strategy on improving growth and yield of maize while saving fertilizer use in small-scale dryland maize farming system.
\end{abstract}

Key words: Africa, maize grain yield, nitrogen management, precision agriculture.

\section{Introduction}

Maize (Zea mays L.) is a crop adaptable to wide range of climatic conditions and is used as a staple food in most parts of Southern Africa. Maize is largely produced in the rural parts of the Northern

Corresponding author: Matshwene Edwin Moshia, Ph.D., research fields: precision agriculture, soil sciences, geographic information system, land use planning and geostatistics. E-mail: matshwene.moshia@fulbrightmail.org. provinces of South Africa, which includes the Limpopo Province. In the Limpopo Province of South Africa, out of 1,554,161 ha of cultivated agricultural land, 767,104 ha is occupied by small-scale farmers, that's $49.35 \%$ of cultivated agricultural land [1]. Soils of the areas that are predominantly occupied by small-scale farms are inherently low on productivity [2]. In addition to low productivity of soils, a significant decline in maize production was observed 
as a result of rural farmer's inability to afford sysnthetic fertilizers. There is a need for a feasible method of applying fertilizers efficiently for maximum dryland maize production in rural small-scale farms of the Limpopo Province under semi-arid environment. Despite that, farmers are still applying fertilizers using conventional methods. Several studies have already profiled the use of different fertilizers in rural production areas, particularly by resource poor farmers [3-6]. However, the focus of this study is entirely on the use and application of nitrogen $(\mathrm{N})$ fertilizer.

$\mathrm{N}$ is the most crop yields limiting nutrient in maize production. To achieve optimum maize grain yields, adequate $\mathrm{N}$ must be available for maize to use during critical growth stages [7]. In semi-arid parts of the Limpopo Province of South Africa, small-scale farmers use traditional and conventional $\mathrm{N}$ management and application strategy for $\mathrm{N}$ fertilizer application. This traditional and conventional $\mathrm{N}$ management and application strategy entails uniform application of $\mathrm{N}$ fertilizers by broadcasting fertilizer application method based on average values from soil analysis results, which disregard spatial variability of soils that may exist in the farmers' agricultural field. When $\mathrm{N}$ fertilizers are applied uniformly in a the entire field, a uniform application rate of $\mathrm{N}$ fertilizer may under- or over-apply fertilizers, resulting in decreased yield and efficiency, and may consequently result in environmental degradation and economic loss $[8,9]$.

Uniform $\mathrm{N}$ fertilization on an agricultural field that exhibit spatial variability results in low $\mathrm{N}$ use efficiency (NUE) because $\mathrm{N}$ becomes unavailable to maize during critical growth stages [10, 11]. Poor synchrony between soil $\mathrm{N}$ supply and maize demand during $\mathrm{N}$ critical growth stages is considered a major cause of low NUE $[12,13]$. This poor synchrony is a result of large $\mathrm{N}$ pre-plant fertilization that may be unavailable for the crop during the critical growing stages [12]. At present, small-scale farmers in the area where this study was conducted use conventional method of large $\mathrm{N}$ pre-plant fertilization uniformly across the field.

In contrast to conventional $\mathrm{N}$ management strategy, site-specific nutrient management (SSNM) practices advocate a detailed assessment and management of infield spatial variability [14]. With SSNM, correct amount of nutrients are only applied where and when needed. Site-specific nutrient management strategies have potential toward improving $\mathrm{N}$ use efficiency and maize yields [15], particularly for rural farmers who struggle to acquire farm inputs. A two-year season study conducted by Ref. [16] found that SSNM strategy had $11 \%$ and $33 \%$ significantly higher $(P \leq$ $0.05)$ maize grain yield as compared to conventional management strategy. The fertilizer application rate was reduced by $32 \%$ and $29 \%$ for two consecutive seasons, which suggests that application of fertilizers based on site-specific strategy is feasible for maize production and produce optimum yields with minimum fertilizer application [16]. Other studies indicated that site-specific $\mathrm{N}$ management strategy is more economical and environmentally sound, requiring lower rates of $\mathrm{N}$ fertilizer and effectively producing optimum maize grain yields when compared to conventional management strategy [17-19]. While most of these studies were conducted under irrigation and various climatic conditions on commercial farms, this study was conducted under dryland on small-scale farms in South Africa. Therefore, the objective of this study was to assess growth and grain yield of maize under conventional and site-specific $\mathrm{N}$ management strategies in a dryland farming system.

\section{Materials and Methods}

\subsection{Study Area}

Field experiments were conducted over three site-years from 2011 to 2013 in the Limpopo Province of South Africa, particularly covering Sekhukhune and Waterberg districts (Fig. 1). Site-years I, II and III 

Management in a Dryland Farming System

were at Leeeukraal $\left(24.92723942^{\circ} \mathrm{S} ; 29.79986685^{\circ} \mathrm{E}\right)$, Ga-Marishane $\left(24.92723942^{\circ} \mathrm{S} ; 28.34573890^{\circ} \mathrm{E}\right)$ and Radium $\quad\left(25.08956020^{\circ} \mathrm{S} ; \quad 28.26244141^{\circ} \mathrm{E}\right)$, respectively. The long term average rainfall and temperature for site-years I and II is $450 \mathrm{~mm}$ and $20.7{ }^{\circ} \mathrm{C}$, respectively, with minimum and maximum average temperatures of $14.2^{\circ} \mathrm{C}$ and $29.6{ }^{\circ} \mathrm{C}$. Site-year II has long term average rainfall and temperature of 620 $\mathrm{mm}$ and $20.4{ }^{\circ} \mathrm{C}$, with minimum and maximum temperatures of $12.7^{\circ} \mathrm{C}$ and $28.8^{\circ} \mathrm{C}$, respectively. Soils were classified as deep red sandy clay loam rhodic ferralsols, food and agricultural organization. The study site-years $i$ and ii were fallowed and cultivated with vegetables, and site-year III was fallowed and cultivated with sunflower, respectively, in the previous cropping season.

\subsection{Soil Sampling and Analysis}

Soil samples were collected in replicates from geo-referenced locations using systematic unaligned random sampling procedure. Soils were sampled at a depth of $0-20 \mathrm{~cm}$ and $20-60 \mathrm{~cm}$, and coordinates were recorded at each sampling point using a Trimble GeoXM differential GPS receiver (Trimble Corp., Sunnyvale, CA). Soil samples were analyzed for $\mathrm{pH}$ using deionized water at a 1:5 = soil:water ratio [20], digest total $\mathrm{N}$, and nitrate- $\mathrm{N}$, Bray1 phosphorus (P) [21], $1 \mathrm{M}$ ammonium acetate extractable $\mathrm{K}, \mathrm{Ca}, \mathrm{Mg}$ and $\mathrm{Na}$ [20]. Soil analysis results are presented in Table 1.

\subsection{Land Preparation and Planting}

Soil was prepared using mouldboard plough and conventionally tilled for fine seedbed. Phosphorus fertilizer was applied through band placement by a planter in all plots at a rate of $42 \mathrm{~kg} \mathrm{P} / \mathrm{ha}$ as single super phosphate $(10.5 \% \mathrm{P})$. Hybrid maize (cultivar SNK 2147) was planted using a mechanical planter mounted to a tractor on a $20 \mathrm{~m}$ by $20 \mathrm{~m}$ plot with inter-row and intra-row spacing of $0.9 \mathrm{~m}$ and $0.35 \mathrm{~m}$, respectively. In site-years I and II, maize was planted in the month of December while site-year III was planted in the month of January and this was informed by the climatic chart.

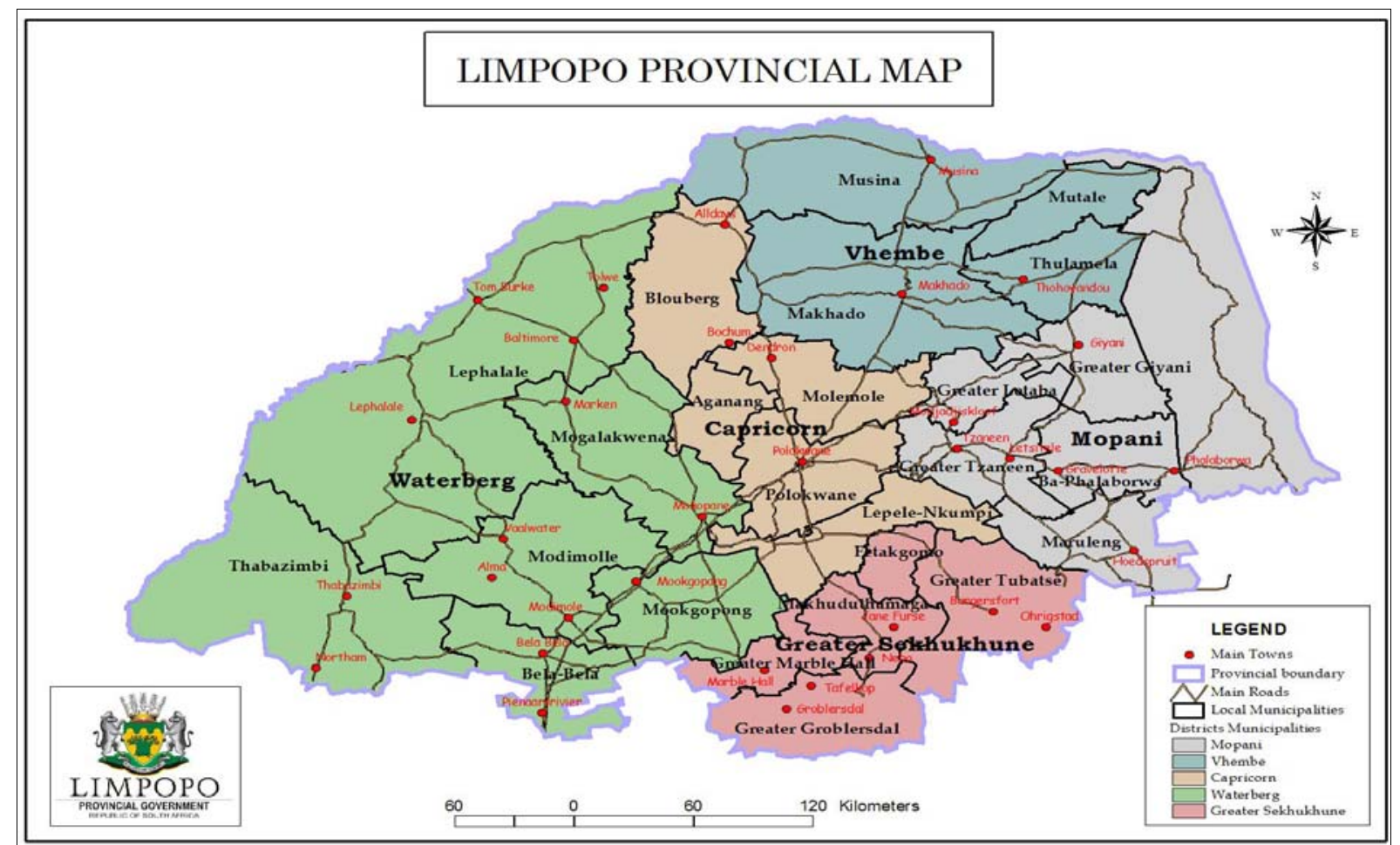

Fig. 1 Map of the Limpopo Province of South Africa showing all five districts including Waterberg and Greater Sekhukhune Districts. 
Table 1 Soil analysis of selected soil properties in the 0-20 cm and 20-30 cm of soil profile at site-years (SY) I, II and III in the Limpopo Province.

\begin{tabular}{lllll}
\hline Parameter & $\mathrm{cm}$ & SY I & SY II & SY III \\
\hline \multirow{2}{*}{$\mathrm{pH}\left(\mathrm{H}_{2} \mathrm{O}\right)$} & $0-20$ & 5.7 & 6.8 & 6.1 \\
& $20-30$ & 5.7 & 7.1 & 6.0 \\
\hline \multirow{2}{*}{ Total N (mg/kg) } & $0-20$ & 400 & 300 & 300 \\
& $20-30$ & 300 & 200 & 300 \\
\hline \multirow{2}{*}{$\mathrm{P}(\mathrm{mg} / \mathrm{kg})$} & $0-20$ & 1.8 & 13.3 & 8.6 \\
& $20-30$ & 0.5 & 2.6 & 1.8 \\
\hline \multirow{2}{*}{$\mathrm{K}(\mathrm{mg} / \mathrm{kg})$} & $0-20$ & 100 & 147 & 155 \\
& $20-30$ & 91 & 124 & 123 \\
\hline \multirow{2}{*}{$\mathrm{Ca}(\mathrm{mg} / \mathrm{kg})$} & $0-20$ & 193 & 463 & 607 \\
& $20-30$ & 154 & 474 & 588 \\
\hline \multirow{2}{*}{$\mathrm{Mg}(\mathrm{mg} / \mathrm{kg})$} & $0-20$ & 92 & 79 & 2,161 \\
& $20-30$ & 110 & 89 & 207 \\
\multirow{2}{*}{$\mathrm{Na}(\mathrm{mg} / \mathrm{kg})$} & $0-20$ & 0.06 & 8.40 & 9.20 \\
& $20-30$ & 1.01 & 9.90 & 8.60
\end{tabular}

Soil pH using soil: water solution method [20], total N: total N digest standard method; P: Bray1 method [21]; $\mathrm{K}, \mathrm{Ca}, \mathrm{Mg}$ and Na: $1 \mathrm{M}$ ammonium acetate extraction [20].

\subsection{Treatment Application}

The experimental plots were laid in a randomized complete block design and replicated four times. Treatments for the study were three $\mathrm{N}$ management strategies, (i) no $\mathrm{N}$ application (N0), (ii) site-specific $\mathrm{N}$ application (N1) and (iii) conventional $\mathrm{N}$ application (N2). Nitrogen fertilizer for the N2 nitrogen management strategy was applied at a uniform rate of $58 \mathrm{~kg} \mathrm{~N} / \mathrm{ha}$, equivalent to what farmers' use; as determined from soil analysis results with the expected grain yield of 3 $\mathrm{Mg} / \mathrm{ha}$ [22]. Nitrogen fertilizer was broadcasted during maize planting as blanket application for the N2 experimental plots. These N2 management strategy is the conventional method used by farmers in the region, hence, $\mathrm{N}$ is applied at planting as opposed to V6 growth stage. The no $\mathrm{N}$ fertilizer application (N0) was used as control plots. The N fertilizer rates for the $\mathrm{N} 1$ nitrogen management strategy varied across the study sites, that is, 18, 22 and $33 \mathrm{~kg} \mathrm{~N} / \mathrm{ha}$ for site-years III, I and II, respectively. Nitrogen fertilizer was top-dressed in the maize rows as N1 treatment, based on
Chlorophyll Content Meter-200 readings (Opti-Sciences, USA). Nitrogen deficiency in crops was determined through non-destructive sensing of maize leaves during high $\mathrm{N}$ demand peak period for maize vegetative growth stage V6 (six leaf growth stage), V10 and V14. Sufficiency index (SI), determined from the reference crop and the sensed crop using Chlorophyll Content Meter-200 was used as an indication for the need of $\mathrm{N}$ fertilization. Nitrogen fertilizer was applied only when needed [23]. The field areas of N0, N1 and N2 plots were $400 \mathrm{~m}^{2}$, i.e., $20 \mathrm{~m}$ long and $20 \mathrm{~m}$ wide. Two reference plots were established with an area of 100 $\mathrm{m}^{2}$, i.e., $20 \mathrm{~m}$ by $5 \mathrm{~m}$. Sufficiency index was determined using the formula given by Ref. [24].

$$
S I=(\text { VI sensed crop/VI reference }) \times 100 \%
$$

where, VI sensed crop is the vegetation index (or measurement) of the sensed crop, from the N1 plot, and VI reference is the vegetation index of the non- $\mathrm{N}$ limited crop, from the reference plot.

Peterson et al. [24] specified that $S I \leq 95$ denotes N deficiency; hence top-dressing of $\mathrm{N}$ fertilizer is necessary. The recommended $\mathrm{N}$ rate for $3 \mathrm{Mg} /$ ha grain yield is $58 \mathrm{~kg} \mathrm{~N} / \mathrm{ha}$. Nitrogen application rate for the N1 was based on the rate of $S I$ and the percentage of the recommended $\mathrm{N}$ for $3 \mathrm{Mg} / \mathrm{ha}$ grain yield. When $S I$ was $0-23,24-47,48-71,72-95$ and $>95$, the following recommendations of $100 \%, 75 \%, 50 \%, 25 \%$ and $0 \%$ of the recommended $\mathrm{N}$ fertilizer rate were applied, respectively. Limestone ammonium nitrate fertilizer $(28 \% \mathrm{~N})$ was used as source of $\mathrm{N}$. Weeds were managed through manual weeding, which is the common method used by the farmers in these farming areas; and stalk borer pesticide was used to manage stalk and stem borer.

\subsection{Data Collection and Analysis}

Growth data, which included maize height, number of leaves per plant, leaf breadth and leaf length and leaf area were collected during the maize growth stages V6, V10 and V14. Leaf area was determined 
using the formula given by Ref. [25],

$$
\text { Leaf area }=L \times B \times k
$$

where, $L=$ leaf length $(\mathrm{cm}), B=$ leaf breadth $(\mathrm{cm}), k=$ shape factor with value of 0.75 for maize [25].

Grain yield, grain rows per cob, cob mass per plant (cob with grain) and 100 seed mass data were recorded at harvest. The growth and yield data were subjected to analysis of variance through statistical analysis system (SAS) package. Mean separation tests were computed using Duncan's multiple range test at alpha level of 0.05 and 0.01 [26].

\section{Results and Discussion}

\subsection{Maize Growth Components}

Maize height at site II was $1.06 \mathrm{~m}$ and $1.07 \mathrm{~m}$ for $\mathrm{N} 1$ and N2 strategy, respectively, which was significantly higher $(P \leq 0.05)$ than $0.893 \mathrm{~m}$ of N0 strategy during V10 growth stage. Maize height at site-year III (Fig. 2) of N2 and N1 strategy was significantly higher $(P \leq 0.05)$ than the N0 during growth stage V6. From the four experimental units of the N1 strategy, $\mathrm{N}$ fertilizer was applied to two experimental units that indicated $\mathrm{N}$ deficiency during V6 growth stage. Hence, the highest $(P \leq 0.05)$ maize height during V10 growth stage resulted from N1 strategy; with no significant difference between the N0 and N2 strategy as indicated on Fig. 2. During the V14 maize growth stage, maize height of N1 management strategy was observed to be higher $(P \leq$ $0.05)$ than the N0 strategy. However, there was no significant difference $(P \leq 0.05)$ on maize height between N2 and N1 strategies (Fig. 2) at site-year III.

Number of leaves at site-year II for N2 and N1 strategy of 13 and 12, respectively, were statistically similar. However, the number of leaves for the two strategies was significantly higher $(P \leq 0.05)$ than the 10 leaves under the N0 strategy during growth stage V14.

Site specific management strategy at site-year III (Fig. 3) had significantly higher $(P \leq 0.05)$ number of leaves per plant than the N0 strategy. However, N2 strategy had the highest $(P \leq 0.01)$ number of leaves than the two management strategies during V6 vegetative growth stage. The highest number of leaves

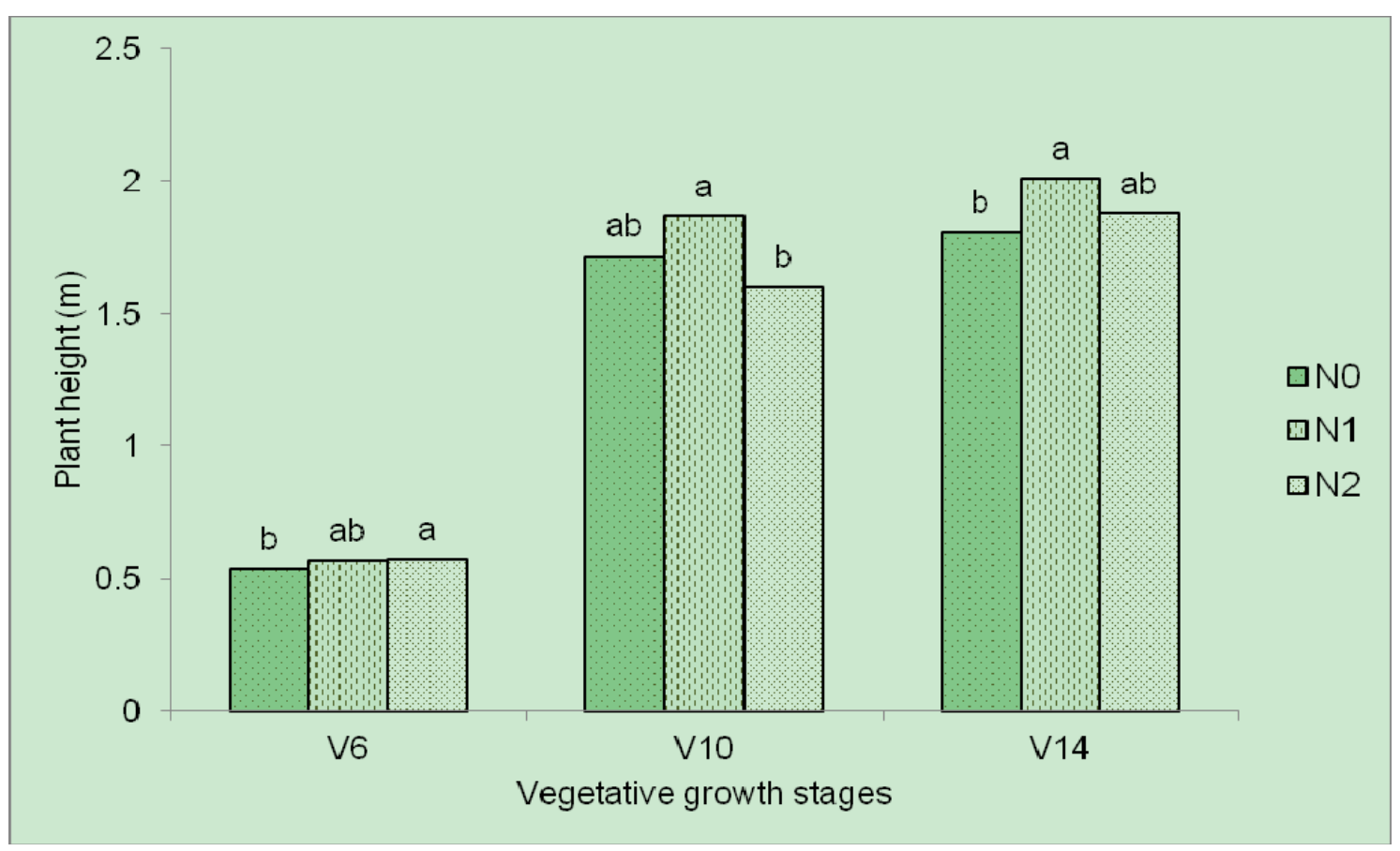

Fig. 2 Maize height at different maize vegetative growth stages under treatments N0, N1 and N2.

Treatment N0 is no nitrogen fertilization, N1 is site-specific N application, and N2 is conventional and uniform N fertilization at site-year III. The mean bars with different alphabetic letter are significantly different at $P \leq 0.05$. 


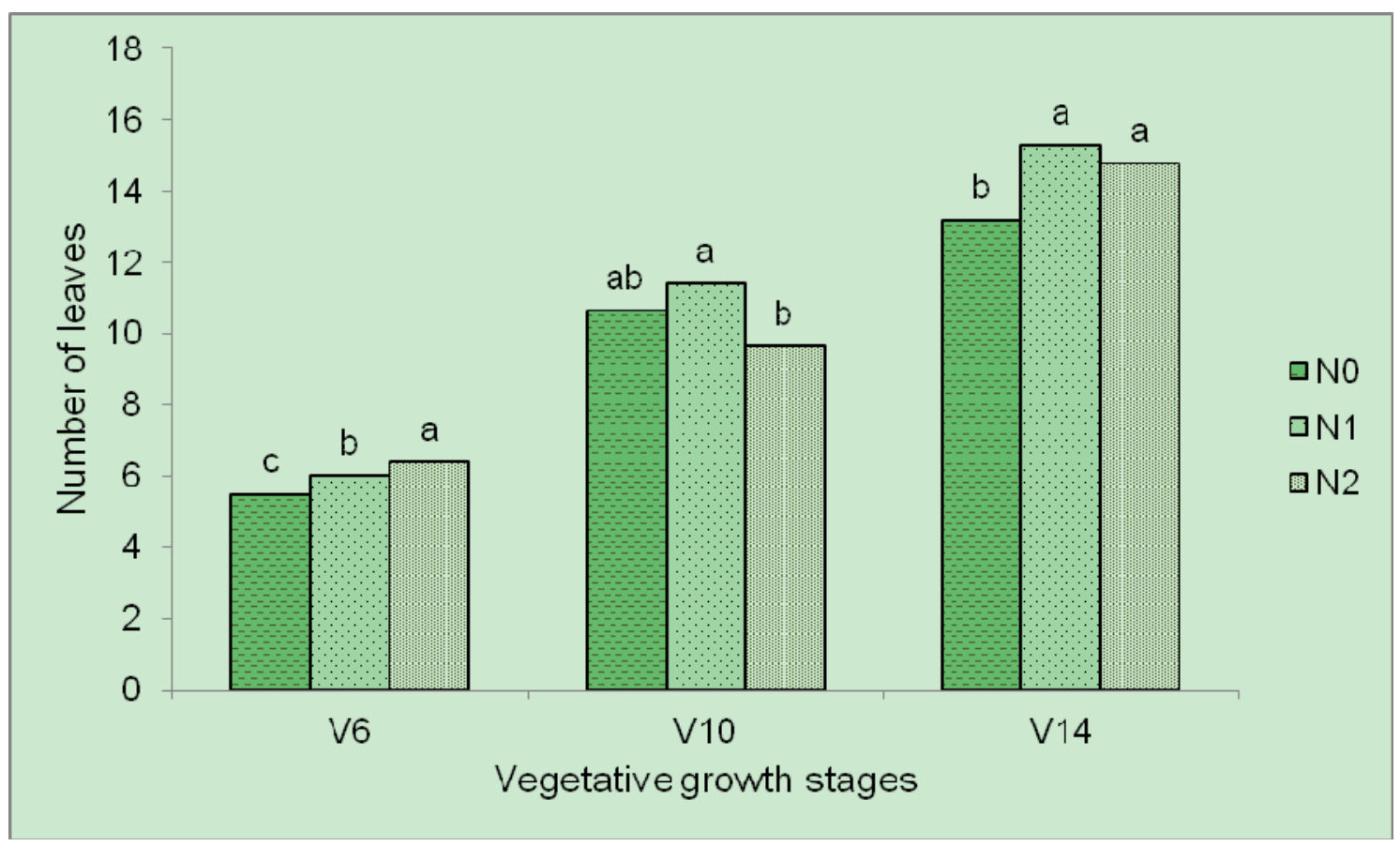

Fig. 3 Number of leaves at different maize growth stages under treatments N0, N1 and N2.

Treatment N0 is no nitrogen fertilization, N1 is site-specific N application, and N2 is conventional and uniform N fertilization at site-year III. The mean bars with different alphabetic letter are significantly different at $P \leq 0.05$.

per plant was recorded for N1 strategy during V10 growth stage; while number of leaves for N2 strategy was not significantly different from N0 strategy (Fig. 3). Number of leaves at site-year III for $\mathrm{N} 1$ and $\mathrm{N} 2$ management strategies was statistically the same and both strategies had significantly higher $(P \leq 0.01)$ number of leaves than N0 strategy during V14 growth stage. Number of leaves per plant is proportional to photosynthesis rate and grain production [27]. The more the number of leaves per plant, the higher the photosynthetic rate is leading to positive crop growth and this has a potential to result in better crop yield. Leaf length at site-year III of $0.97 \mathrm{~m}$ for N1 strategy was significantly $(P \leq 0.05)$ longer than $0.78 \mathrm{~m}$ of $\mathrm{N} 0$ strategy during V14 growth stage. There was no significant difference between $0.9 \mathrm{~m}$ leaf length of N2 and N1 strategies. Furthermore no significant difference on the leaf length between N2 and N0 strategies was found during V14 growth stage at site-year III (Fig. 3).

Leaf area was significantly higher at site-year III for site-specific N management strategy than N0 and N2 strategies during V10 growth stages (Fig. 4). The leaf area showed no significant difference between the N0 and N2 strategies during V10 growth stage. During $\mathrm{V} 14$ growth stage, leaf area for N1 and N2 strategies was not significantly different; however, both strategies had significantly higher leaf area than N0 strategy at site-year III.

Maize plant height at site-years II and III showed that optimum maize height can be reached through N1 $\mathrm{N}$ management strategy. Maize height is an important crop growth and yield component, and height has a direct proportionality to 100 grain mass [27].

Maize height is also positively correlated with grain yield; the higher the plant height, the better the crop yields are [28]. Nitrogen fertilizer was top-dressed during V6 growth stage for N1 strategy; while for the $\mathrm{N} 2$ strategy, $\mathrm{N}$ fertilizer was only applied during maize planting for all site-years. High number of leaves and leaf area during V10 and V14 growth stages and leaf length during V14 growth stage for N1 strategy at site-year III was achieved with $69 \%$ lesser $\mathrm{N}$ fertilizer than N2 strategy. This can attributed to best 


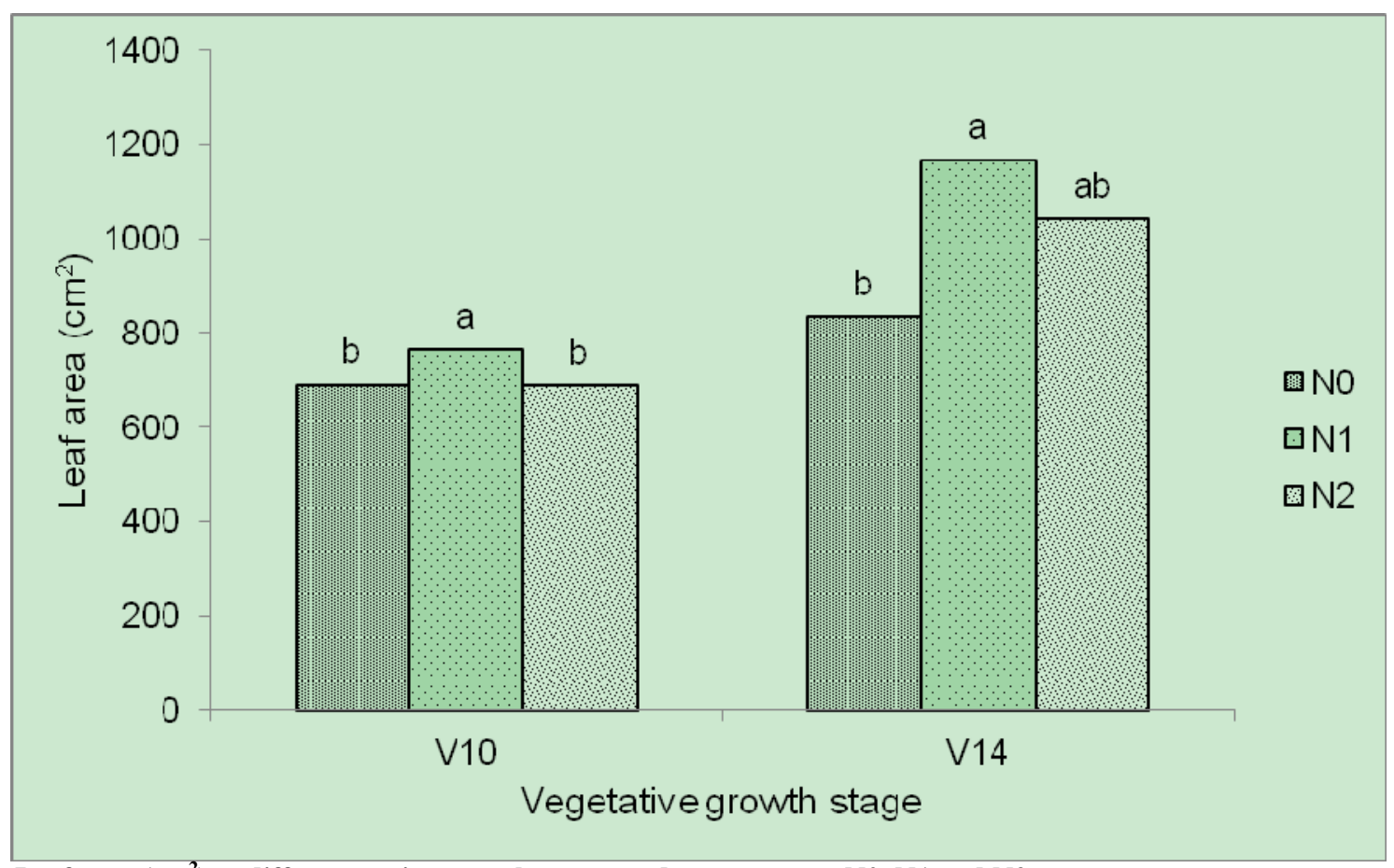

Fig. 4 Leaf area $\left(\mathrm{cm}^{2}\right)$ at different maize growth stages under treatments N0, N1 and N2.

Treatment N0 is no nitrogen fertilization, N1 is site-specific N application, and N2 is conventional and uniform N fertilization at site-year III. The mean bars with different alphabetic letter are significantly different at $P \leq 0.05$.

Table 2 Maize yield components and grain yield under three $\mathbf{N}$ management approaches at site-years I and II.

\begin{tabular}{lllllllll}
\hline \multirow{2}{*}{ Treatment } & \multicolumn{2}{c}{ No. of grain rows/cob } & \multicolumn{3}{c}{ Cob mass/plant $(\mathrm{g})$} & \multicolumn{2}{c}{ 100 grain mass (g) } & \multicolumn{2}{c}{ Grain yield (t/ha) } \\
\cline { 2 - 9 } & SY I & SY II & SY I & SY II & SY I & SY II & SY I & SY II \\
\hline N0 & $11^{\mathrm{b}}$ & $14^{\mathrm{a}}$ & $195^{\mathrm{a}}$ & $168^{\mathrm{b}}$ & $34^{\mathrm{a}}$ & $28^{\mathrm{b}}$ & $3.2^{\mathrm{b}}$ & $1.7^{\mathrm{c}}$ \\
$\mathrm{N} 1$ & $13^{\mathrm{a}}$ & $13^{\mathrm{a}}$ & $234^{\mathrm{a}}$ & $194^{\mathrm{b}}$ & $37^{\mathrm{a}}$ & $33^{\mathrm{a}}$ & $5.2^{\mathrm{a}}$ & $2.2^{\mathrm{b}}$ \\
$\mathrm{N} 2$ & $13^{\mathrm{a}}$ & $14^{\mathrm{a}}$ & $204^{\mathrm{a}}$ & $233^{\mathrm{a}}$ & $36^{\mathrm{a}}$ & $29^{\mathrm{b}}$ & $4.0^{\mathrm{ab}}$ & $2.6^{\mathrm{a}}$ \\
Significance & $* *$ & $\mathrm{~ns}$ & $\mathrm{~ns}$ & $* *$ & ns & $* *$ & $*$ & $*$ \\
LSD $_{0.05}$ & 1.51 & - & & 35.9 & - & 3.0 & 1.3 & 0.2 \\
CV & 5.3 & 5.1 & 16.0 & 10.5 & 3.4 & 5.9 & 13.7 & 6.4 \\
\hline
\end{tabular}

Treatment N0 is no nitrogen fertilization, N1 is site-specific N application, and N2 is conventional and uniform N fertilization at site-years I and II. LSD = Least significant difference, $\mathrm{CV}=$ coefficient of variation, ns $=$ non-significant, $* *$ significant at $P \leq 0.01$, *significant at $P \leq 0.05$. Means with same letter within the same category did not differ significantly from one another at $P \leq 0.05$.

timing for $\mathrm{N}$ application, thus synchronizing $\mathrm{N}$ demand and $\mathrm{N}$ supply.

The availability of $\mathrm{N}$ in the soil is influenced by soil $\mathrm{pH}$; soil $\mathrm{pH}$ of site-years II and III were 6.0 and 7.1, respectively (Table 1). Maize is reported to have optimum performance at soil $\mathrm{pH}$ between 5.8 and 7.0 [29]. Nitrogen fertilizer has a significant effect on maize leaf area, leaf length and number of leaves per plant [30]. Available $\mathrm{N}$ during maize critical growth stage of V6 may have promoted vigorous growth, improved meristematic, and physiological activities in maize, and consequently resulting in improved maize growth parameters.

\subsection{Maize Yield Components}

Number of grain rows per cob at site-year of N1 and N2 strategy was higher $(P \leq 0.01)$ than the N0 strategy (Table 2). No significant difference on the number of rows per cob between N1 and N2 strategy was found. The number of maize grain rows per cob and cob mass per plant are important yield components. Alvi et al. [31] and Bocanski et al. [32] 
reported 100 grain mass to be positively correlated to grain yield, making it one of the essential yield determinant. Small-scale farmers broadcast all N fertilizer at an average rate during maize planting following N2 strategy. The significantly higher grain rows per cob, and 100 grain mass of N1 and N2 strategy than N0 strategy justify that optimum yield components can be achieved using minimal $\mathrm{N}$ fertilization following N1 strategy. Site-specific N management strategy takes spatial variability into consideration. The N1 strategy not only required lesser $\mathrm{N}$ than $\mathrm{N} 2$ strategy, but also improved crop growth and development that contributed to maize yield components [33].

The cob mass per plant at site-year II of N2 N management strategy $(233 \mathrm{~g})$ was significantly higher $(P \leq 0.01)$ than $168 \mathrm{~g}$ and $194 \mathrm{~g}$ of N0 and N1 N management strategies, respectively (Table 2 ). There was no significant difference on the cob mass per plant between N0 and N2. The 100 grain mass at site-year II under N1 strategy was significantly higher $(P \leq 0.01)$ than the N0 and N2 strategies (Table 2). The $\mathrm{N} 0$ and $\mathrm{N} 2$ strategies had no significant difference on the 100 grain mass at site-year II (Table 2).

\subsection{Maize Grain Yield}

Maize grain yield at site-year I of $5.2 \mathrm{Mg} /$ ha for N1 strategy was significantly $(P \leq 0.05)$ higher than 3.2 $\mathrm{Mg} / \mathrm{ha}$ of the N0 (Table 2). In the same site-year, grain yield of N1 strategy was not significantly different to $4.0 \mathrm{Mg} / \mathrm{ha}$ of $\mathrm{N} 2$. The maize grain yield (Table 2) at site-year II of $2.2 \mathrm{Mg} / \mathrm{ha}$ for N1 strategy was significantly higher $(P \leq 0.01)$ than $1.7 \mathrm{Mg} / \mathrm{ha}$ of the N0 strategy. The highest $(P \leq 0.01)$ grain yield of 2.6 $\mathrm{Mg} /$ ha was recorded from N2 strategy at site-year II.

Although there was no statistical difference on grain yield at site-year I between N1 and N2 strategies, $\mathrm{N} 1$ strategy outperformed N2 strategy by $1.2 \mathrm{Mg} / \mathrm{ha}$ of grain yield. Farmers consider grain yield difference of $1.2 \mathrm{Mg} / \mathrm{ha}$ an improvement on grain yields given that $\mathrm{N} 1$ strategy required $63 \%$ lesser $\mathrm{N}$ fertilizer than $\mathrm{N} 2$ strategy. Grain yield results align with the results reported by Refs. [33, 16] that site-specific $\mathrm{N}$ applications improves crop growth and development and consequently promotes better maize grain yields. Rainfall followed immediately after $\mathrm{N}$ fertilizer was top-dressed on the N1 strategy. In South Africa, for many years dryland maize producers learned to synchronize planting dates with climatic data, making it easy to top-dress $\mathrm{N}$ at V6 stage without losing $\mathrm{N}$ through volatilization. Rainfall dissolved the top-dressed $\mathrm{N}$ fertilizer, making $\mathrm{N}$ available to maize during $\mathrm{N}$ sensitive stages on N1 strategy of site-year I.

The significantly higher grain yield at site-year II for N1 than N0 strategy align with the findings of Ref. [34] that yield is reduced when $\mathrm{N}$ fertilizer is not applied, more especially under dryland. Despite the $0.4 \mathrm{Mg} /$ ha higher grain yield for N2 at site-year II than $\mathrm{N} 1$ strategy; the amount of N fertilizer used under N1 strategy was $43 \%$ lesser than the N2 strategy. Uniform broadcast of $\mathrm{N}$ fertilizer across the farm during maize planting is an inefficient $\mathrm{N}$ management strategy, as maize does not use $\mathrm{N}$ until growth stage $\mathrm{V} 6$ [35]. The $0.4 \mathrm{Mg} / \mathrm{ha}$ lower grain yield under N1 strategy is attributed to the unavailability of $\mathrm{N}$ during critical maize growing stages [12], as a result of low precipitation. Nitrogen uptake and distribution in crops are affected by soil moisture, which is influenced by rainfall in a dryland farming system such as where this study was conducted [36, 37]. In dryland farming system, it is important to synchronize $\mathrm{N}$ fertilizer top-dressing with rainfall by taking rainfall forecasts into consideration so that $\mathrm{N}$ can be readily available to maize in order to achieve better yield in a dryland farming system.

\section{Conclusions}

Site-specific $\mathrm{N}$ management strategy required between $43 \%$ and $69 \%$ lesser $\mathrm{N}$ fertilizer as compared to conventional $\mathrm{N}$ management strategy over site-years, and resulted in higher maize height, number of leaves per plant, leaf length and leaf area 
than that of conventional $\mathrm{N}$ management strategy. The use of site-specific $\mathrm{N}$ management strategy has potential towards improving maize grain yield in South African dryland farming system within a resource poor rural environment. The highest grain yield of $5.2 \mathrm{Mg} /$ ha was achieved through site-specific $\mathrm{N}$ management strategy at site-year I. This study has therefore demonstrated the efficiency of applying $\mathrm{N}$ fertilizer on site-specific in rural farming under dryland, taking into consideration reduction in input costs and environmental efficiency, while not compromising the yield through site-specific $\mathrm{N}$ management strategy. In examining the results of these studies, there was a consistent benefit of site-specific $\mathrm{N}$ management strategy on improving growth of maize while saving on fertilizer use in dryland maize farming system.

\section{References}

[1] Munyai, F. R. 2012. "An Evaluation of Socio-Economic and Biophysical Aspects of Small-Scale Livestock System Based on a Case Study from Limpopo Province: Muduluni Village." Ph.D. thesis, University of Free State.

[2] Mamanyuha, L. 2012. "Evaluation of Three Commercial Composts Used by Small-Scale Farmers in Limpopo Province, South Africa." Master thesis. University of Limpopo, Sovenga.

[3] Odhiambo, J. J., and Magandini, V. 2008. "An Assessment of the Use of Mineral and Organic Fertilizers by Smallholder Farmers in Vhembe District, Limpopo Province, South Africa." African Journal of Agricultural Research 3 (5): 357-62.

[4] Baloyi, T. C., Thobakgale, M. D., and Kutu, F. R. 2009. "Crop Rotation and Fertilizer Effect on Productivity and Nutritional Demands of Small-Scale Farmers in Dry Land Areas of South Africa." In Proceedings of the 9th African Crop Science Conference, 17-21.

[5] Meliko, M. O., and Oni, S. A. 2011. "Input-Output Analysis on the Contribution of Agriculture to the Economy of Limpopo Province, South Africa." Afr. J. Agric. Res. 6 (29): 6303-10.

[6] Petja, B. M., Mashego, S., Maluleke, W., Nkoana, R. A., Lekalakala, R. G., and Ramugondo, R. R. 2012. "Evaluation of Fertilizer Application in Relation to Farm Specific Soil Potential for Different Crops at Nandoni: A Preliminary Survey." Limpopo Policy Research Repository. Accessed November 2013. http:// www.policyresearch.limpopo.gov.za/handle/123456789/1 $5 b$.

[7] Robertson, G. P., and Vitousek, P. M. 2009. "Nitrogen in Agriculture: Balancing an Essential Resource." Annual Reviews of Environmental Resources 34: 97-125.

[8] Khosla, R., Anderson, C. M., Alley, M. M., and Noble, R. 1999. "Phosphorous and Potassium Fertilizer Recommendation Variability for Two Mid-Atlantic Coastal Plain Fields." Soil Science Society of America Journal 63 (6): 1740-7.

[9] Thrikawala, S., Weersink, A., Kachanoski, G., and Fox, G. 1999. "Economic Feasibility of Variable-Rate Technology for Nitrogen on Corn." American Journal of Agricultural Economics 81 (4): 914-27.

[10] Shahandeh, H., Wright, A. L., Hons, F. M., and Lascano, R. J. 2005. "Spatial and Temporal Variation of Soil Nitrogen Parameters Related to Soil Texture and Corn Yield." Agronomy Journal 97 (3): 772-82.

[11] Hong, N., Scharf, P. C., Davis, J. G., Kitchen, N. R., and Sudduth, K. A. 2007. "Economically Optimal Nitrogen Rate Reduces Soil Residual Nitrate." Journal of Environmental Quality 36 (2): 354-62.

[12] Cassman, K. G., Dobermann, A., and Walters, D. T. 2002. "Agroecosystems, Nitrogen-Use Efficiency and Nitrogen Management." Ambio. 31 (2): 132-40.

[13] Fageria, N. K., and Baligar, V. C. 2005. "Enhancing Nitrogen Use Efficiency in Crop Plants." Advances in Agronomy 88: 97-185.

[14] Berry, J. K., Delgado, J. A., Khosla, R., and Pierce, F. J. 2003. "Precision Conservation for Environmental Sustainability." Journal of Soil and Water Conservation 58 (6): 332-9.

[15] Hornung, A., Khosla, R., Reich, R., and Westfall, D. G. 2003. "Evaluation of Site Specific Management Zones: Grain Yield and Nitrogen Use Efficiency." In Proceedings of the 4th European Conference on Precision Agriculture, 15-9.

[16] Lan, Y., Zhang, S., Li, W., Hoffmann, W. C., and Ma, C. 2008. "Variable Rate Fertilization for Maize and Its Effects Based on the Site-Specific Soil Fertility and Yield." Agricultural Engineering International 5 (12): 1629-62.

[17] Koch, B., Khosla, R., Frasier, W. M., Westfall, D. G., and Inman, D. 2004. "Economic Feasibility of Variable-Rate Nitrogen Application Utilizing Site-Specific Management Zones.” Agronomy Journal 96 (6): 1572-80.

[18] Paz, J. O., Batchelor, W. D., and Colvin, T. S. 1997. "Calibration of a Crop Growth Model to Predict Spatial Yield Variability." Paper American Society of Agricultural Engineers (971031): 19.

[19] Khosla, R., Fleming, K., Delgado, J. A., Shaver, T., and Westfall, D. G. 2002. "Use of Site Specific Management 


\section{Management in a Dryland Farming System}

Zones to Improve Nitrogen Management for Precision Agriculture." J. Soil and Water Conservation 5 (7): 513-8.

[20] Mclean, E. O. 1982. "Soil pH and Lime Requirement." In Methods of Soil Analysis, edited by Page, A. L. et al., Madison: American Society of Agronomy, 199-223.

[21] Bray, R. H., and Kurtz, L. T. 1945. "Determination of Total, Organic and Available Form of Phosphorus in Soil." Soil Science Society of America Journal 59 (1): 39-46.

[22] Fertilizer Society of South Africa (FSSA). 2007. Fertilizer Handbook. 6th ed., South Africa: Lynnwood Ridge.

[23] Thabang, S. M., Moshia, M. E., Shaker, P., and Fouché, P. S. 2012. "The Economic Impact of Infield Spatial Variability in a Uniformly Managed Small-Scale Corn (Zea mays L.) Field." African Journal of Agricultural Research 7 (31): 4416-26.

[24] Peterson, T. A., Blackmer, T. M., Francis, D. D., and Schepers, J. S. 1993. Using a Chlorophyll Meter to Improve $N$ Management (Neb Guide). Lincoln, USA: Institute of Agriculture and Natural Resources, University of Nebraska.

[25] Montgomery, E. G. 1911. "Correlation Studies in Corn." Nebraska Agricultural Experimental Station Annual Report 24: 108-59.

[26] Littel, R. C., Stroup, W. W., and Freund, R. J. 2002. SAS for Linear Models. 4th ed., Cary: SAS Institute Inc..

[27] Saidaiah, P., Satyanarayana, E., and Sudheer, K. S. 2008. "Association and Path Coefficient Analysis in Maize (Zea mays L.)." Agricultural Science Digest 28 (2): 79-83.

[28] Tenaw, W. 2000. "Effect of Nitrogen Fertiliser Rates and Plant Density on Grain Yield of Maize." African Crop Science Journal 8 (3): 273-82.

[29] Grier, C. C., Lee, K. M., Nadkarni, N. M., Klock, G. O., and Edgerton, P. J. 1989. Productivity of Forests of the United States and Its Relation to Soil and Site Factors and Management Practices: A Review. General technical report.

[30] Kaur, A., Bedi, S., Gill, G. K., and Kumar, M. 2012. "Effect of Nitrogen Fertilizers on Radiation Use Efficiency, Crop Growth and Yield in Some Maize (Zea mays L.) Genotypes." Maydica 57 (1): 75-82.

[31] Alvi, M. B., Rafique, M., Tariq, M. S., Hussain, A., Mahmood, T., and Sarwar, M. 2003. "Character Association and Path Coefficient Analysis of Grain Yield and Yield Components Maize (Zea mays L.)." Pakistan Journal of Biological Science 6 (2): 136-8.

[32] Bocanski, J., Sreckov, Z., and Nastasic, A. 2009. "Genetic and Phenotypic Relationship between Grain Yield and Components of Grain Yield of Maize (Zea mays L.)." Genetika 41 (2): 145-54.

[33] Raun, W. R., Solie, J. B., Johnson, G. V., Stone, M. L., Mullen, R. W., Freeman, K. W., Thomason, W. E., and Lukina, E. V. 2002. "Improving Nitrogen Use Efficiency in Cereal Grain Production with Optical Sensing and Variable Rate Application." Agronomy Journal 94: 815-20.

[34] Sallah, P. Y. K., Ehlke, N. J., and Geadelmann, J. L. 1998. "Progress from Selection in La Posta Maize Population Evaluated under Three Nitrogen Fertilizer Levels." African Crop Science Journal 6 (3): 241-8.

[35] Barbieri, P. A, Echeverría, H. E, Saínz Rozas, H. R, and Andrade, F. H. 2008. "Nitrogen Use Efficiency in Maize as Affected by Nitrogen Availability and Row Spacing." Agronomy Journal 100: 1094-100.

[36] Ottman, M. J., and Welch, L. F. 1988. "Supplemental Radiation Effects on Senescence, Plant Nutrients and Yield of Field Grown Corn." Agronomy Journal 80 (4): 619-26.

[37] Okalebo, J. R., Palm, C. A., Gichuru, M., Owuor, J. O., Othieno, C. O., Munyampundu, A., Muasya, R. M., and Woomer, P. L. 1999. "Use of Wheat Straw, Soybean Trash and Nitrogen Fertiliser for Maize Production in the Kenyan Highlands." African Crop Science Journal 7 (4): 423-31. 